\title{
SIMÓN BOLÍVAR: O TRATAMENTO DAS REBELIÕES POPULARES COMO UM PROBLEMA EDUCACIONAL
}

\author{
SIMÓN BOLÍVAR: EL TRATAMIENTO DE LAS REBELIONES POPULARES COMO \\ UN PROBLEMA EDUCACIONAL
}

SIMÓN BOLÍVAR: HANDLING THE POPULAR REBELIONS AS NA EDUCATIONAL
PROBLEM

Alex de Novais DANCINI ${ }^{1}$

José Joaquim Pereira MELO ${ }^{2}$

RESUMO: Em dois documentos escritos por Simón Bolívar, fica evidente que ele compreendia a não adesão dos setores populares à causa criolla anticolonialista como um problema de educação, de virtude e moral, ou de falta dela, e não das contradições raciais e sociais do período. Com esse eixo norteador, analisa-se neste artigo o conteúdo do Manifesto de Cartagena, no qual Bolívar interpreta os principais fatos que levaram à queda da Primeira República (1811-1812) e à retomada do poder pelos espanhóis. Analisa-se também o Manifesto de Carúpano, produzido em 1814, depois da perda da Segunda República para os espanhóis, cuja força principal era o exército popular de José Tomás Boves.

PALAVRAS-CHAVE: Independência na Venezuela. Simón Bolívar. Educação.

RESUMEN: En dos de los documentos escritos por Simón Bolívar, es evidente que el comprendía la no adhesión de los sectores populares a la causa anticolonialista criolla como un problema de educación, de virtud y moral, o de la falta de ella, y no de las contradicciones raciales y sociales del período. Con ese eje de pensamiento, se analiza en este texto el contenido del Manifiesto de Cartagena, en el cual Bolívar interpreta los acontecimientos principales que causaron la derrocada de la Primera República (1811-1812) y llevaron los españoles a retomar el poder. También se analiza el Manifesto de Carúpano, escrito en 1814, después de la pérdida de la Segunda República para los españoles, que tenían en el ejército popular de José Tomás Boves su principal fuerza.

PALAVRAS CLAVE: Independencia en Venezuela. Simón Bolívar. Educación.

ABSTRACT: Two documents by Simón Bolivar reveal that he understood that the nonadhesion of the people to the anticolonial criolla cause as an educational issue, comprising virtue and morals, or its lack, rather than an issue of the racial and social contradictions of

\footnotetext{
${ }^{1}$ Doutorando do Programa de pós-Graduação em Educação da Universidade Estadual de Maringá. Bolsista PDSE CAPES - 2015; Professor no Colegiado de Educação da Unniversidade Estadual do Paraná - UNESPAR. Membro do Grupo de Pesquisa Transformações Sociais e Pensamento Educacional (GPTSPE/UEM). E-mail: alexdancini@hotmail.com

${ }^{2}$ Professor Doutor do Programa de Pós-Graduação em Educação da Universidade Estadual de Maringá (UEM). E-mail: pereirameloneto@ hotmail.com
}

RIAEE - Revista Ibero-Americana de Estudos em Educação, v. 12, n. 2, p. 755-775. , $2017 . \quad$ E-ISSN: 1982-5587 
the period. From this perspective, the contents of the Cartagena Manifesto are analyzed, in which the Liberator of the Americas interprets the main facts that brought about the fall of the First Republic (1811-1812) and the re-appropriation by the Spaniards. The 1814 Carúpano Manifesto is also investigated, after the loss of the Second Republic for Spain, whose strength lay with the people's army led by José Tomás Boves.

KEYWORDS: Independence of Venezuela. Simón Bolívar. Education.

\section{Introdução}

A independência da América espanhola é um tema rico para o debate historiográfico e, por essa razão, é alvo de análise neste texto. Como espaço e tempo históricos, definiu-se a Venezuela dos primeiros anos do século XIX. Nesse período, na Capitania Geral da Venezuela, território composto por dez províncias ${ }^{3}$, surgiram vários movimentos anticolonialistas, até que, em 5 de julho de 1811, foi proclamada, formalmente, a independência dessa nação.

O objetivo específico é acompanhar o pensamento de Simón Bolívar, especialmente a respeito do distanciamento que, nos quatro primeiros anos de guerra, os setores populares (negros, pardos, mulatos, mestiços, zambos, índios) mantiveram da luta anticolonialista proposta pelos criollos. Discutem-se as concepções políticas e sociais que orientaram o projeto político republicano do Libertador em 1819, no interior do qual ele elaborou também seu projeto educacional. Assim, a abordagem se inscreve no debate historiográfico da educação latino-americana.

Foram privilegiados dois documentos escritos por Bolívar: Manifesto de Cartagena e Manifesto de Carúpano. O primeiro contém uma análise sociológica dos primeiros momentos da guerra de independência e, principalmente, dos equívocos que levaram os republicanos a perder a Venezuela para os espanhóis. Esse documento marca o início da trajetória de Bolívar como político, cujas ideias seriam utilizadas para a conquista de seu objetivo. Não se registram textos anteriores nos quais ele tenha apresentado reflexões políticas e sociológicas como resultado de sua maneira de interpretar o cenário venezuelano imerso em sua fase bélica inicial. O segundo documento foi escrito em 7 de setembro de 1814, poucos meses depois da queda da Segunda República.

A escolha desses documentos deve-se ao fato de que ambos contêm reflexões posteriores às derrotas (de 1812 e de 1814) do exército patriota liderado por Bolívar e à

${ }^{3}$ No ano de 1800, as dez províncias somavam uma população de 898.043 habitantes, segundo os censos da época (BRITO FIGUEROA, 1974, p. 160).

RIAEE - Revista Ibero-Americana de Estudos em Educação, v. 12, n. 2, p. 755-775. , $2017 . \quad$ E-ISSN: 1982-5587 
retomada do poder político pelos espanhóis. Com base neles, é possível discutir a posição bolivariana diante das derrotas sofridas, bem como o papel desempenhado pelos setores populares nesses acontecimentos. Tendo em vista essas fontes, o texto está estruturado em duas partes, além das considerações finais.

A primeira é dedicada a reflexões sobre o Manifesto de Cartagena. Contextualizandose historicamente o documento, procura-se identificar qual é a interpretação que Bolívar faz dos setores populares e de sua relação com os desdobramentos da guerra. Em seus termos, a virtude e a ignorância eram as causas do afastamento popular da luta independentista. Bolívar atribui o fracasso inicial do movimento de independência à falta de educação (moral) dos participantes, principalmente daqueles que faziam parte dos setores marginalizados da sociedade, e não às contradições sociais e raciais da época.

A segunda parte é voltada para o Manifesto de Carúpano, escrito em 1814. Segundo o autor, esse foi o pior momento de todo o movimento independentista. Além de o exército patriótico estar destruído física e moralmente, Bolívar enfrentava o descontentamento de alguns de seus oficiais que não o reconheciam mais como comandante em chefe. Nesse mesmo ano, os criollos haviam enfrentado a revolta dos setores populares comandados por Boves. A preocupação em torno da possibilidade de um levante popular era constante entre os setores dominantes e isso se tornou realidade em 1814. O resultado foi a queda da Segunda República. Com base no documento em tela, pode-se inferir que ele, novamente, relaciona a rebelião popular com a educação (moral) dessas massas, sem contemplar a situação social em que viviam.

Nas considerações finais, destaca-se que o tema se torna importante à medida que colabora para o debate historiográfico da educação latino-americana: analisam-se as bases interpretativas que, no início do século XIX, levaram Simón Bolívar a propor uma educação estatal, gratuita, obrigatória e com um destacado sentido moral para a Venezuela.

\section{Manifesto de Cartagena: a questão da ignorância popular}

O conteúdo do Manifesto de Cartagena é todo voltado à análise do fracasso político e militar dos criollos republicanos, que resultou na queda da Primeira República. Em 5 de julho de 1811, os deputados do Congresso Nacional venezuelano, chamado também de Junta Suprema Conservadora de los Derechos de Fernando VII, aprovaram a proclamação de independência das províncias unidas de Venezuela. Tal proclamação ocorreu em meio a uma 
disputa política interna no setor mantuano ${ }^{4}$. O Congresso, espaço seleto de homens brancos e ricos, defendia a autonomia política colonial e a fidelidade ao Rei; já a Sociedade Patriótica, círculo de debates políticos mais radicais, da qual participava Bolívar e outros criollos, mas também pardos e mulheres (MASUR, 1987), optava pela total ruptura política. Pressionado pela Sociedade Patriótica, o Congresso venezuelano proclamou a primeira independência da colônia espanhola na América.

A fragmentação dos interesses políticos dos setores dominantes foi um dos fatores decisivos para a precoce queda da Primeira República, que ocorreu apenas um ano depois de sua proclamação. Outro fator importante foi a indiferença com que os setores populares trataram o movimento libertário dos brancos criollos (ACOSTA, 2014). A correlação de forças políticas tinha peso no sucesso do projeto independentista e foi completamente desfavorável para os patriotas venezuelanos na primeira fase da guerra $(1811$ - 1815). Ou seja, os ricos americanos colonialistas, os espanhóis e os setores populares, compostos por negros livres, escravos, mulatos, índios, zambos e mestiços, não se alinhavam com a proposta independentista.

Em cinco de julho de 1811, proclamada a independência, coube a Francisco de Miranda $^{5}$ o comando político e militar da República, enquanto que os defensores dos interesses espanhóis eram comandados militarmente por Domingo de Monteverde (1773$1832)^{6}$.

Depois de serem derrotados pelo general espanhol Monteverde, no início do mês de julho de 1812, alguns patriotas venezuelanos acabaram sendo presos e mortos pelos espanhóis, diante do descumprimento do acordo de capitulação feito entre Miranda e Monteverde. Bolívar conseguiu sair de Caracas, chegar a La Guayra e fugir para Cartagena de Índias (território da atual Colômbia).

Cartagena estava sob o poder dos republicanos de Nova Granada e configurava-se como um ponto estratégico para se retomar o combate com os espanhóis e libertar novamente a Venezuela. A estratégia de Bolívar encontrou a resistência de outros oficiais venezuelanos que ali estavam e também dos deputados do Congresso de Nova Granada (FRANK, 2006).

\footnotetext{
${ }^{4} \mathrm{Na}$ Venezuela, esse termo é utilizado como sinônimo de criollo.

${ }^{5}$ Francisco de Miranda nasceu em Caracas em 28 de março de 1750 e morreu em 14 de julho de 1816, quando estava preso em Cádiz, Espanha. Figura reconhecida em toda a Europa, foi o primeiro venezuelano a elaborar um projeto de independência para a América espanhola.

${ }^{6}$ Juan Domingo de Monteverde y Ribas, espanhol nascido em Tenerife em 1773, tornou-se um reconhecido militar espanhol. No momento em que a independência da Venezuela foi proclamada, em cinco de julho de 1811, Monteverde foi enviado para aplacar a rebeldia dos criollos. Obteve êxito ao enfrentar Miranda em 1812, mas foi derrotado por Simón Bolívar no ano seguinte, quando se restabeleceu a Segunda República da
} Venezuela.

RIAEE - Revista Ibero-Americana de Estudos em Educação, v. 12, n. 2, p. 755-775. , $2017 . \quad$ E-ISSN: 1982-5587 
Diante das dificuldades para convencer seus aliados políticos, ele escreveu alguns documentos sobre a Primeira República venezuelana, apresentando sua leitura dos mais diversos acontecimentos daquele período. Em Memória dirigida a los ciudadanos de Nueva Granada por um Caraqueño ele aprofundou suas análises e revelou, pela primeira vez, suas ideias políticas sobre a forma de governo, o caráter da guerra contra os espanhóis e a situação cultural da colônia, sobretudo dos setores pobres (ACOSTA, 2015).

Um dos temas norteadores da discussão encaminhada por Bolívar nesse documento foi a defesa de um governo centralista em oposição ao modelo federativo. A fragmentação de interesses sociais e regionais era, segundo ele, prejudicial para ordenar a república em seu estágio inicial (BOLÍVAR, 1968). Sua crítica ao modelo federativo tem dois pontos fundamentais. O primeiro diz respeito ao estado cultural da maioria da população, que impedia que sua participação na vida política da república fosse positiva. Como carecia de virtude republicana, essa população colocaria em risco a paz e a felicidade de toda a nação (BOLÍVAR, 1982). A segunda tem relação direta com a situação de guerra de então, a qual necessitava de respostas rápidas por parte do governo. Uma federação não favoreceria essa rapidez necessária: antes de tomar qualquer decisão de atacar o inimigo, seria preciso consultar pessoas e aguardar a aprovação de várias instâncias de poder. A opção de Bolívar pelo centralismo como forma de governo teve, portanto, o aspecto cultural e o bélico como ordenadores gerais.

Para ele, a perda da Primeira República foi um erro político, na medida em que se preferiu adotar a federação em vez do centralismo. Isso fez com que as decisões de atacar Monteverde tardassem para ser tomadas, permitindo o avanço das tropas inimigas. Por outro lado, o modelo federativo não condizia com a realidade cultural da maioria da população, impedindo, assim, a existência de um governo executivo forte, capaz de impor a liberdade àqueles que, segundo ele, não a compreendiam: “[...] fundando la Junta su política en los principios de humanidad mal entendida que no autorizan a ningún gobierno, para hacer por la fuerza libres a los pueblos estúpidos que desconocen el valor de sus derechos" (BOLÍVAR, 1968, p. 117).

Do ponto de vista de um representante do setor mantuano, ao se referir a povos estúpidos que desconhecem seus direitos, Bolívar analisava a indiferença dos setores populares em relação à independência. De modo geral, esta era a maneira como todo o setor criollo via aquele movimento. Os princípios liberais de liberdade e igualdade estavam limitados aos setores proprietários, cujo objetivo era se livrar da Espanha. Ao mesmo tempo, 
persistiria a exclusão social e racial, isto é, a falta de liberdade e igualdade entre os venezuelanos dos setores socialmente marginalizados

A Constituição de 1811 manteve intacta a escravidão. A liberdade era exclusiva dos setores dominantes em relação ao poder monárquico espanhol e significava a substituição do súdito pelo cidadão. Ou seja, a liberdade e a igualdade republicanas de 1811 não foram estendidas aos escravos, zambos, mulatos, mestiços e índios. O objetivo dos criollos era manter a ordem social existente na colônia. O problema é que, de abril de 1810 até julho de 1811, os termos liberdade e igualdade circulavam por todas as cidades das províncias, levando os setores populares a ver nesse movimento uma oportunidade de melhoria de suas condições sociais. De acordo com a proposta dos setores dominantes, a proclamação da república não mudaria nenhuma estrutura social. No entanto, isso só ficou claro no momento em que se proclamou o documento que daria vida política à República. Proclamada a constituição, os setores populares comprovaram que não faziam parte das mudanças que até então eram anunciadas. O relato de José Domingo Díaz, um espanhol que defendeu, até aonde foi possível, a continuidade da Monarquia espanhola na Venezuela, ofereceu uma dimensão da euforia política que tomou conta de toda a população de Caracas em cinco de julho:

Este dia funesto fue uno de los más crueles de mi vida. Aquellos jóvenes, en el delírio de su triunfo [...] despedazaran y arrastraron las banderas y escaparelas españolas. [...] Yo los vi correr por las calles en mangas de camisa y llenos de vino, dando alaridos y arrastrando los retratos de S.M., que habían arrancado de todos los lugares en donde se encontraban. Aquellos pelotones de hombres de la revolución, negros, mulatos, blancos, españoles y americanos corrían de una plaza a outra, en donde oradores energúmenos incitaban al populacho al desenfreno y a la licencia (DÍAZ, 2012, p. 26).

De um modo ou de outro, escravos, negros livres, mulatos, mestiços e zambos foram envolvidos no movimento de independência e acreditavam que seria possível mudar alguma coisa daquela realidade desigual. Todavia, com a proclamação da constituição, perceberam que tudo havia permanecido como antes, e a euforia dos setores populares transformou-se em desconfiança e revolta contra os setores dominantes.

Uma vez iniciados os confrontos militares entre os patriotas e os defensores da Monarquia espanhola, os setores de cor que, em 1800, representavam em torno de $70 \%$ da população da Capitania Geral da Venezuela (BRITO FIGUEROA, 1974, p. 160), ficaram, de modo geral, alheios à luta. Sem seu apoio, o movimento de independência tinha poucas chances de vencer, militarmente, os espanhóis. 
A reflexão de Bolívar sobre a não adesão dos setores populares ao ideal de independência tinha como pressuposto a ignorância, a falta de uma formação moral adequada a tais princípios. Ou seja, o problema estava mais relacionado ao intelecto do que às próprias condições materiais em que eles viviam. As condições de desigualdade social e racial da época eram tidas como naturais pelos criollos. Estes consideravam que a recusa de boa parte dos negros, mulatos, mestiços e zambos em participar da causa independentista era uma traição ao ideal de pátria e soberania que movia a luta.

Além disso, havia mais um fato com o qual os escravos conviviam nesse primeiro momento da guerra e que não os agradava. Eles tinham que ir para as batalhas a mando de seus amos e morrer por uma causa que não era deles, sem nem mesmo terem ganhos imediatos concretos, como terra ou dinheiro, da mesma forma que ocorria com outros soldados.

Os setores populares, principalmente os negros escravos, conheciam "o valor dos seus direitos", mas não os direitos abstratos oferecidos pela constituição de 1811 (ACOSTA SAIGNES, 1997). O que eles não reconheciam era a promessa de liberdade e igualdade, esta não os alcançava, e reagiam contra seus amos, aproveitando a propícia situação da guerra civil, colocando os criollos em uma complicada situação. A República se desfazia diante da indiferença popular, ao mesmo tempo que esses setores aproveitavam o momento para expor e lutar por suas reivindicações históricas: "Ya los mantuanos iban recogiendo poco a poco sus frutos de libertades ideales, de papel, viendo que el equilíbrio que era la base de superponderancia social empezaba a resquebrajarse" (PIETRI, 2014, p. 37).

No Manifesto de Cartagena, também é possível verificar que a concepção de sociedade que Bolívar elaborou seria o fundamento sociológico de seu projeto de educação estatal, gratuito e obrigatório apresentado em 1819. Em 1812, antes mesmo de enfrentar o período agudo da revolta social dos setores populares, que ocorreria dois anos mais tarde, ele entendia que a formação/educação pela qual haviam passado no período colonial era a responsável pela atitude de descaso para com o projeto de independência. Para ele, a formação predominante nesse período fora marcada pelo predomínio da religião, que, por sua vez, impedia que os setores desprovidos de conhecimentos compreendessem a independência política como um fato positivo. A maioria dos religiosos regulares e seculares era contra a independência, o que dificultava ainda mais a situação dos criollos rebeldes.

Segundo Bolívar, essa histórica atuação religiosa era a responsável pela indisposição desses setores em relação à luta política pela emancipação política, pois os formara para viver sob a superstição religiosa e a obediência cega ao Rei (BOLÍlVAR, 1969). E acrescentava: 
"Un corto número de sucesos por parte de nuestros contrarios, ha desplomado el edifício de nuestra gloria, estando la masa de los pueblos descarriada por el fanatismo religioso [...] y por la doctrina de la supersticón" (BOLÍVAR, 1976, p. 43).

Considerando, assim, os complexos fatores envolvidos naquele movimento político e social, ele estabeleceu o modo como o Estado deveria se comportar diante daquela realidade:

Es preciso que el gobierno se identifique, por decirlo así, al carácter de las circunstancias, de los tiempos y de los hombres que lo rodean. Si estos son prósperos y serenos, él debe ser dulce y protector; pero si son calamitosos y turbulentos, él debe mostrarse terrible, y armarse de una firmeza igual a los peligros, sin atender a leyes y constituciones, ínterin no se restablece la felicidad y la paz (BOLÍVAR, 1968, p. 120).

Nesse momento, sem considerar a possibilidade, por exemplo, da abolição da escravatura e da igualdade social dos pardos, Bolívar acreditava que o Estado devia conduzir a massa "desafecta a la causa, inepta, ignorante y inmoral" (BOLÍVAR, 1968, p. 121) pela força das armas e/ou pela educação de caráter moralizador. A formalização e a divulgação de seu projeto educacional ocorreram sete anos depois, quando, em substituição à Carta Magna de 1811, ele apresentou ao Congresso de Angostura o Projeto de Constituição para a Venezuela.

O estabelecimento de um paralelo entre 1812 e 1819 neste texto deve-se ao fato de que, já em seu primeiro documento de análise política e social da guerra de independência, Bolívar definira a base interpretativa de sua proposta educacional para a república. A educação estatal, pública, gratuita e obrigatória, deveria, de acordo com sua interpretação, levar moral e luzes para as massas ignorantes, com a finalidade de estruturar uma sociedade de felicidade e paz, controlada, econômica e politicamente, pelos brancos criollos, mas sem tocar nos problemas sociais existentes. Sua máxima "Moral e Luzes são nossas primeiras necessidades" é o fundamento de sua proposta educacional e, ao mesmo tempo, resultado de sua compreensão das condições sociais da Venezuela, o que o leva a estabelecer, como estadista, os deveres do Estado para garantir a legitimação do projeto criollo de república. No que diz respeito à educação, o Estado deveria garantir a formação moral necessária para o consenso em torno desse projeto.

Entretanto, a independência implicava algumas mudanças, ainda que tímidas. A proposta educacional de Bolívar foi uma dessas novidades que sinalizaram para uma mudança, mas como não foi acompanhada de transformações estruturais, não alterou os padrões sociais da época. Tais mudanças apontam para dois extremos: em um deles, a manutenção, a qualquer custo, do poder econômico e político nas mãos dos criollos; no outro, 
a inserção dos setores populares na vida republicana, de uma forma completamente passiva do ponto de vista político, sem participação nas eleições ou cargos públicos. Assim, eles seriam mantidos na mesma condição colonial de trabalhadores das fazendas e dos serviços urbanos e domésticos, ou seja, socialmente inferiores, aos olhos dos brancos ricos, que não aceitavam nenhum benefício em favor dos grupos de cor.

No final do século XVIII, por exemplo, o governo espanhol tinha se proposto a dar mais mobilidade social aos pardos e criar leis para aumentar a proteção dos escravos. Junto a essas mudanças, estava a possibilidade de tornar a educação pública aberta também aos pardos. Até então, as crianças pardas ou de qualquer setor de cor eram proibidas de frequentar escolas públicas: a única forma de instrução com a qual podiam contar era a dos ensinamentos de artesãos, majoritariamente de cor, que abriam escolas em suas próprias oficinas. Para os brancos espanhóis e americanos, a medida significava uma afronta aos modos sociais da hierarquia social na colônia. Os brancos levantaram-se contra o governo, em defesa de seu status quo social. Para Lynch,

Este hecho simplemente acentuó de forma notoria la susceptibilidad respecto a la raza e hizo aumentar los recelos criollos hacia los pardos, los indios y los esclavos. La política imperial los enojó porque la consideraban demasiado indulgente respecto a los pardos y los esclavos. La élite criolla se opuso tercamente al avance de la gente de color, protestó por la venta de los certificados de blancura y se resistió a la extensión de la educación popular y al ingreso de los pardos en la universidad. Entre otras cosas, se vieron afectados por la pérdida de la fuerza de trabajo en un período de expansión de la hacienda y de crecimiento de las exportaciones (LYNCH, 1991, p. 24).

Dessa maneira, sem abandonar sua posição de classe e sem tocar na continuidade da exclusão social, Bolívar inseria as massas no projeto político social dominante. Ao mesmo tempo, precisava avançar na questão da hierarquização social a respeito das raças. Do ponto de vista educacional, ele rompeu com a sociedade colonial ao defender que, na república, a educação de primeiras letras deveria estar à disposição de todas as crianças. Os limites dessa defesa eram os mesmos contidos no projeto republicano bolivariano, de tal maneira que as reformas sociais que poderiam oferecer as mínimas condições materiais para a realização desse ideal não fizeram parte do mesmo projeto.

Ao mesmo tempo em que avançava na defesa da educação pública e obrigatória para todas as crianças, Bolívar situava-a no interior de um projeto político e social maior, que não tocava na continuidade dos privilégios dos setores dominantes, o que o impedia de realizar reformas estruturais. Sua proposta de uma educação popular era um dos avanços necessários para que os setores dominantes não perdessem o controle do todo social, já que, para ele, era a 
ignorância e a falta de virtude e moral republicanas que fazia com que os setores populares não apoiassem a independência: "Si los criollos tenían un ojo puesto sobre sus amos, tenían el otro sobre sus sirvientes. Los criollos eran muy conscientes de la presión social existente desde abajo y se esforzaron por mantener a distancia a la gente de color" (LYNCH, 1991, p. 23).

A novidade em Bolívar é que, em seu ideal de república, essa vigilância seria exercida pelo Estado e a educação elementar generalizada seria uma das manifestações desse controle. Foram as contradições inerentes às transformações sociais que apresentaram a possibilidade de mudança para todos os setores daquela sociedade, mas a vitória, em curto prazo, seria decidida pelos grupos de maior poder econômico, os quais manteriam intactos seus privilégios.

\section{Manifesto de Carúpano: a ignorância como causa da rebelião popular de 1814}

O Manifesto de Carúpano, para muitos de seus estudiosos, é um dos textos mais expressivos do final de 1814. É por meio dele que Bolívar se dirige a seus concidadãos para se contrapor às críticas que ele e seus oficiais vinham sofrendo por terem perdido a Segunda República para os espanhóis. Essa fase da guerra de independência tem um caráter importante, já que foi nesse ano que os criollos republicanos mais sofreram com a violência dos escravos, que, em troca da liberdade prometida, seguiam os espanhóis, e com os ataques dos mestiços, zambos e mulatos dos $\operatorname{llanos}^{7}$ venezuelanos.

Os llanos eram compostos por grandes fazendas de pastagens, cuja produção de carne e couro figurava como uma das importantes atividades de exportação da Capitania, ao lado do cacau, açúcar e tabaco (BRITO FIGUEROA, 1974). Grande parte das famílias que estavam à frente do movimento independentista possuía fazendas nessas regiões. Segundo Brito Figueroa (1974, p. 71), os grupos familiares Mier y Terán, Ponte, Blanco, Tovar, Bolívar, Villegas, Toro, Blanco Uribe, Blanco Villegas, Blanco Ponte, Bolívar Villegas, Bolívar Blanco, Rodrígez del Toro são alguns dos que aparecem como proprietários. Segundo o mesmo autor, "esas fazendas constituían auténticos latifundios ganaderos; la frase no es simplemente literaria, corresponde a la realidad de la propiedad territorial en las comarcas

\footnotetext{
${ }^{7}$ A região da Venezuela que é chamada de llanos caracteriza-se por uma grande extensão de terras planas e de grandes rios navegáveis. Sua planície deu origem a um espaço típico da criação de gado.

RIAEE - Revista Ibero-Americana de Estudos em Educação, v. 12, n. 2, p. 755-775. , $2017 . \quad$ E-ISSN: 1982-5587 
llaneras, caracterizadas por el monopolio de la tierra, mano de obra regida fundamentalmente por relaciones de servidumbre, a veces de esclavitud" (BRITO FIGUEROA, 1974, p. 71).

Em 1814, essa região foi a base da formação das tropas comandadas por José Tomás Boves. Nesse ano, as contradições e a luta de classes, no plano social e racial, aprofundaramse e levaram mulatos, negros escravos e negros libertos, que viviam nos llanos venezuelanos, a seguir Boves, comandante de tropas que faziam parte do exército espanhol.

Quando ainda era adolescente, Boves, filho de uma família pobre de espanhóis, foi matriculado no curso de piloto naval do Real Instituto Asturiano. Terminou o curso aos 16 anos de idade e se tornou piloto de embarcações mercantes. No começo do século XIX chegou à costa Venezuelana, passando a ser comerciante na região, conhecida por suas extensas pastagens, propícias para a criação de gado. $\mathrm{O}$ contrabando com a Inglaterra, Holanda e México era prática comum nos llanos, cuja abundância de grandes rios facilitava a prática. Boves era um dos principais comerciantes (contrabandistas) da região e conhecia a cultura dos negros fugidos, dos mulatos e dos índios que povoavam a região e viviam da criação de gado (PIETRI, 2014).

A entrada de Boves na guerra ocorreu depois de sua prisão na cidade de Calabozo, acusado pelos patriotas de fazer campanha contra os republicanos por trazer notícias das vitórias de Monteverde. Para os republicanos, a ação de Boves enfraquecia o movimento republicano na cidade. Conseguindo a liberdade depois que o general realista Antoñanzas dominou a cidade e expulsou os patriotas, ele se ofereceu para lutar nas fileiras realistas, organizando seu exército com homens acostumados ao campo, à uma vida rústica e aventureira nos llanos.

Esse era o território em que Boves vivia e no qual formou o exército que o acompanhou nas campanhas de 1814. Negros fugidos (cimarrones), escravos, índios, zambos, mulatos e mestiços formavam seu grupo de combate. Sob seu comando estavam mais de cinco mil homens, dos quais não mais que 50 eram brancos (PIETRI, 2014). Sua entrada na guerra de independência mobilizou setores daquela sociedade, que vivia uma verdadeira guerra civil. Dessa maneira, a guerra não havia colocado em lados opostos venezuelanos e espanhóis, como se esperava de uma guerra internacional. Era, sobretudo, uma guerra civil. O confronto era entre os próprios venezuelanos que se dividiam nas frentes de combate realistas e republicanas (ACOSTA, 2014).

Antes da chegada de Boves, a guerra de independência não oferecia aos setores populares nenhuma garantia de que sua luta pela igualdade social, no caso dos pardos, pelo fim da escravidão dos negros africanos e pelo fim do trabalho servil de campesinos e índios 
seria contemplada na nova sociedade republicana, fundada nos conceitos liberais de igualdade, liberdade, propriedade e seguridade. Logo de início, havia ficado claro que esses conceitos não eram para todos.

Diferentemente da divisão classista e racial que existia na sociedade colonial e que persistia durante a Primeira e Segunda República, o comerciante dos llanos prometia igualdade social aos pardos, fim da escravidão aos negros, liberdade aos índios, terras para essa massa de expropriados e morte aos brancos criollos, republicanos ou não. A própria organização do exército tinha outra característica com Boves. No caso do exército patriota, os oficiais mantuanos mantinham a hierarquia militar tal qual se apresentava nas relações sociais e raciais excludentes:

La oficialidad patriota era una oficialidad brillante, salida en su mayor parte de las filas del mantuanismo. No consideraban sus tropas como iguales a ellos, sino la trataban con una cierta condescendencia de señor a inferior, pues la mayor parte de aquellos heroicos militares no habían hecho otra cosa que cambiar un mando por otro, el de sus haciendas por el ejército. Predicaban justicia y libertad metafísica, derechos de papel que aquellos soldados no comprendían (PIETRI, 2015, p. 110).

Com Boves, os llaneros se revesavam nos postos de comando mais importantes nas batalhas, desconhecendo a hierarquia que pudesse opor uns aos outros. Ademais, esses setores populares encontraram em seu comandante e na luta contra os brancos, proprietários e republicanos, a possibilidade de lhes devolver os maus tratos e as humilhações pelas quais haviam passado a vida toda. Além do interesse na liberdade e na igualdade sociais, o ressentimento que nutriam foi importante nas batalhas, nos saques às fazendas e nos assassinatos daqueles que tinham como verdadeiros inimigos (CARRERA DAMAS, 1991).

De modo geral, o ano de 1814 representou para o exército patriótico, sob o comando de Bolívar, a mais dura derrota dentre todas as ocorridas nos 10 anos de guerra de independência na Venezuela, até a batalha de Carabobo, em 1821. O movimento popular capitaneado por Boves preocupou até mesmo os espanhóis, que solicitaram de Fernando VII uma intervenção na perigosa aventura popular que havia derrotado os criollos republicanos, mas que não poupava também os brancos espanhóis (ACOSTA, 2014). O líder llanero, vencendo o exército patriota, entrou em Caracas no dia 16 de julho de 1814, estabelecendo-se como governante supremo e colocando negros e pardos nos mais altos cargos do governo. Por um instante, aqueles que eram socialmente invisíveis começaram a comandar uma estrutura de poder que, de certa forma, excluía os brancos realistas de cargos aos quais estavam acostumados. 
No entanto, a inserção social promovida por Boves teve curta duração. O primeiro caudilho venezuelano (PIETRI, 2015) morreu em um combate em cinco de dezembro de 1814. O evento desestruturou suas tropas, que não aceitavam como comandante nem um branco criollo, nem um branco espanhol. Aceitariam apenas alguém que, como ele, soubesse conviver com aquela massa despossuída, que tivesse a capacidade de compreender a cultura llanera de escravos, de escravos fugidos, de índios, mulatos, mestiços e zambos. Juan Uslar Pietri apresenta um dado importante sobre as tropas de Boves: "Boves y Rosete tenían bajo sus ordenes al menos siete u ocho mil hombres, dentro de los cuales no había más que cincuenta blancos o españoles europeus, y mil de color libres; el resto era de esclavos, de negros y zambos” (PIETRI, 2015, p. 113). Esses dados revelam uma característica dos dois exércitos, patriótico e espanhol, nos primeiros anos da guerra. Não houve o confronto entre um exército que se pudesse chamar de venezuelano e outro espanhol. A composição desses dois exércitos era praticamente de venezuelanos. De 1811 a 1814, os patriotas não conseguiram atrair para suas fileiras os negros, zambos, mestiços e mulatos em um número que pudesse reunir força superior à dos espanhóis. A rebelião popular de 1814, cujo desdobramento era temido por republicanos e espanhóis, foi o motivo da derrota republicana e da perda da Segunda República.

Com a retomada do poder político pelos espanhóis, começaram a surgir críticas à maneira como os oficiais criollos conduziam suas tropas: os erros militares eram identificados como causa da derrota republicana. Simón Bolívar redigiu um texto, cujo conteúdo é centrado na defesa incondicional da honra e da virtude dos oficiais criollos, inclusive do próprio Bolívar. O documento, escrito em 7 de setembro de 1814, ficou conhecido como Manifesto de Carúpano. Além da defesa dos oficiais patriotas, o texto também é marcado pela preocupação de mostrar os verdadeiros culpados da queda da Segunda República: estes é que deveriam receber as críticas então dirigidas a Bolívar e a seus oficiais:

Infeliz del magistrado que autor de las calamidades o de los crímenes de su Patria se ve forzado a defenderse ante el tribunal del pueblo de las acusaciones que sus conciudadanos dirigen contra su conducta; pero es dichosísimo aquel que corriendo por entre los escollos de la guerra, de la política y de las desgracias públicas, preserva su honor intacto y se presenta inocente a exigir de sus propios compañeros de infortunio una recta decisión sobre su inculpabilidad (BOLÍVAR, 1969, p. 390).

Em 1812, no Manifesto de Cartagena, Bolívar já apontava como um dos grandes problemas enfrentados pelos independentistas a não adesão dos setores populares à guerra, afirmando também que a ignorância e a falta de conhecimento os impedia de compreender que os criollos brancos, segundo eles próprios, trariam a paz, a felicidade, a igualdade, a 
liberdade e a justiça social. Em 1814, no Manifesto de Carúpano, essa análise tornou-se predominante. A rebeldia popular devia-se à falta de educação, era um problema de moral e de virtude. Essa maneira de entender o problema acompanhou-o até 1815, quando ele escreveu a Carta da Jamaica, considerada como um de seus principais documentos políticos.

É importante notar que, depois de 1816, quando os setores populares, sobretudo as antigas tropas de Boves, passaram a lutar nas fileiras do exército patriota, a ignorância, a falta de virtude e moral não foram mais mencionadas pelo líder independentista.

Entretanto, em 1819, quando a Venezuela organizou seu segundo Congresso como República e o projeto de Constituição foi apresentado por Bolívar, a temática da ignorância, da moral e da ética apareceu como central em sua maneira de organizar o Estado venezuelano. Isso se expressa na proposta de criação de um quarto poder, dividido entre a Câmara da Moral e a da Educação, cujas funções seriam, respectivamente:

Art. $1^{\circ}$. La Cámara de Moral dirige la opinión moral de toda la República, castiga los vícios con el oprobio y la infâmia, y premia las virtudes públicas con los honores y la gloria (BOLIVAR, 1976, p. 130).

Art. $1^{\circ}$. La Cámara de Educación está encargada de la educación física y moral de los niños, desde su nacimiento hasta la edad de doce años cumplidos (BOLÍVAR, 1976, p. 32).

Em sua forma de ordenar o Estado republicano, Bolívar pautava-se nas necessidades que, segundo ele, a própria guerra havia criado. A guerra que os criollos imaginavam entre duas nações tornou-se uma guerra civil entre venezuelanos (VALLENILLA LANZ, 2000), cujo resultado político e humano ${ }^{8}$ foi trágico para os brancos ricos americanos e espanhóis, durante os quatro primeiros anos.

A perda da Segunda República teve um significado muito mais profundo para os mantuanos republicanos, desencadeando uma mistura de frustração e medo. Por um lado, todo o esforço iniciado um ano antes em Nova Granada, bem como a vitória da Campaña Admirable (1813), havia se perdido. No entanto, o que mais preocupava os setores dominantes era que a guerra de independência havia liberado as forças sociais que eles tanto temiam, mesmo antes da proclamação da independência do dia 5 de julho de 1811:

${ }^{8}$ Vallenilla Lanz (2000, p. 33) expressa como a guerra civil de independência na Venezuela destruiu boa parte do conjunto humano, cultural e político dos criollos: "Porque Venezuela ganó in gloria lo que perdió em elementos de reorganización social, en tranquilidad futura y en progreso moral y material efectivos. Nosotros dimos a la independencia de América todo lo que tuvimos de grande: la flor de nuestra sociedad sucumbió bajo la cuchilla de la barbárie, y de la clase alta y noble que produjo Simón Bolívar no quedaba después de Carabobo (batalha que garantiu a independência definitiva da Venezuela, em 21 de junho de 1821) sino unos despojos vivientes que vagaban dispersos por las Antillas y otros despojos mortales que cubrían esse largo camino de glorias desde el Avila hasta el Potosí” (VALLENILLA LANZ, 2000, p. 33).

RIAEE - Revista Ibero-Americana de Estudos em Educação, v. 12, n. 2, p. 755-775. , $2017 . \quad$ E-ISSN: 1982-5587 
El miedo a una insurrección al estilo haitiano de los esclavos y de los pardos libres, que conjuntamente sumaban más de la mitad de la población de Venezuela, explica la cautela de la clase alta criolla. Al mismo tiempo, el miedo a las masas fue una importante razón para no dejar el mantenimiento del orden en manos de los representantes de un gobierno español debilitado y aparentemente indigno de confianza, que en varias ocasiones ya se había mostrado demasiado inclinado a satisfacer las aspiraciones de los pardos (BUSHNELL, 1991, p. 78)

Nos termos de Bolívar, não tinham sido os espanhóis que os haviam derrotado, mas sim as massas de escravos, mulatos, mestiços, zambos e índios: "Así, parece que el cielo para nuestra humillación y nuestra gloria ha permitido que nuestros vencedores sean nuestros hermanos y que nuestros hermanos únicamente triunfen de nosotros" (BOLÍVAR, 1969, p. 391). Mesmo depois de uma intensa rebelião popular contra os proprietários de terras e de escravos, sua análise continuou sendo uma transposição ideológica do seu setor social para os setores populares, isto é, ele concebia a revolta contra os criollos como uma traição à pátria, já que significava o impedimento à realização dos princípios liberais defendidos pelos republicanos. A luta pela liberdade e pela igualdade tinha um sentido prático para os setores dominantes, o da liberdade mercantil e do controle do Estado.

Nos primeiros anos da guerra, Bolívar não conseguia entender quais eram os sentidos práticos que a independência política da Venezuela poderia ter na vida dos setores populares. Assim, era recorrente os americanos ricos falarem em liberdade e igualdade e, ao mesmo tempo, manterem a escravidão, já que eles a viam como uma instituição social natural.

No cotidiano dos setores socialmente marginalizados, os valores defendidos por Bolívar e seu setor social não tinham validade prática. Por isso, quando Boves prometeu a liberdade aos escravos, a morte aos brancos ricos e a cessão de suas propriedades aos negros, pardos pobres, mulatos, mestiços e zambos, reuniu em torno de oito mil homens para suas tropas. Para esses homens, a oportunidade de conquistar algo por meio dos saques e a possibilidade de receber propriedades como forma de pagamento pelo serviço militar, além de certa liberdade para matar os brancos, chamavam mais sua atenção e tinha mais relação com sua vida material do que os princípios proclamados nos Direitos dos Cidadãos e praticamente copiados para a Constituição venezuelana de 1811.

Em 1814, diferentemente de Boves, Bolívar não podia, e nem estava em seu horizonte, oferecer propriedades e tampouco a liberdade aos escravos. Em sua concepção criolla de sociedade, as condições estruturais de existência, isto é, as contradições entre um pequeno número de proprietários e cerca de $75 \%$ da população venezuelana desprovida de propriedade, direitos civis e políticos (BRITO FIGUEROA, 1974, p. 160) eram decorrências naturais de 
relações sociais comuns. Por isso, ele sempre identificou o problema dessa massa que se levantou contra seus exploradores como espiritual, ou seja, como resultado de uma formação que não lhes permitia compreender o sentido de serem livres: "No es justo destruir los hombres que no quieren ser libres, ni es libertad la que goza bajo el imperio de las armas contra la opinión de seres fanáticos, cuya depravación del espírito los hacen amar las cadenas como los vínculos sociales" (BOLÍVAR, 1969, 391).

Nesse momento em que as contradições sociais e raciais se tornaram mais agudas na guerra civil e social, como líder militar e político, ele reduzia a prática política popular a um problema de educação. Abandonar o aspecto moral e ético como ponto de partida para explicar as contradições sociais que se apresentavam naquele momento significaria para Bolívar atacar os interesses de seu próprio setor social, já que implicaria abandonar a esfera das ideias (moral e ética) para identificar as contradições sociais e raciais oriundas das relações de produção da época.

Toda a campanha ideológica da independência se reduzia aos termos liberdade, igualdade, propriedade e seguridade, conceitos de gênese europeia que tinham um sentido social e político para aquela sociedade. No entanto, ao tentar reproduzir uma transformação política europeia, fundada nesses conceitos, em uma sociedade cujas relações eram ordenadas pelo trabalho escravo e na qual o aspecto racial influenciava sobremaneira o destino dos indivíduos, os criollos se depararam com um grave problema social a ser resolvido: garantir a independência política, sem, ao mesmo tempo, perder nenhum privilégio para os setores populares.

No dia 4 de julho de 1811, Bolívar proferiu um discurso na Junta Patriótica para que seus membros defendessem junto ao Congresso venezuelano a proclamação da independência, como de fato aconteceu um dia depois. Em um discurso curto, mas enfático, entre outras coisas, ele afirma:

[...] Esas dudas son tristes efectos de las antiguas cadenas. Que los grandes proyectos (independência) deben preparase con calma. Trescientos años de calma ¿no bastan? La Junta Patriótica respeta, como debe, al Congreso de la nación, pero el Congreso debe oír a la Junta Patriótica, centro de luces y de todos los intereses revolucionarios (BOLÍVAR, 1968, p. 81).

No entanto, percebe-se que o movimento independentista venezuelano não se deveu a um problema de educação, de ilustração. Os criollos podiam ser ilustrados e continuar sendo súditos, sem problema algum para sua confortável vida e para a manutenção de suas propriedades. As motivações desse movimento eram econômicas e políticas, portanto, 
materiais, e tinham relação direta com a necessidade de controlar os negócios mercantis e estabelecer comércio com nações desenvolvidas, ampliando o mercado internacional para a Venezuela e aumentando sua participação na divisão internacional do trabalho.

Da mesma forma, o fato de a grande maioria dos setores populares se recusar a assumir a causa independentista dos criollos também tinha fundamento nas relações materiais de existência que haviam sido construídas ao longo de três séculos de vida colonial. Não se tratava de um problema de educação, de virtude, mas sim de problemas prático-políticos referentes à liberdade dos escravos, à igualdade jurídica e política dos mestiços, zambos e mulatos, ao respeito às terras indígenas, a outras medidas que pudessem transformar de alguma maneira aquela realidade desigual e excludente.

Da mesma forma como, em seu discurso, Bolívar chamava a atenção para o fato de os criollos estarem há três séculos sob o julgo espanhol e, mesmo assim, terem dúvidas sobre a independência e a necessidade de se apressar a conquista da liberdade, os setores populares, vivendo há três séculos sob as regras de uma sociedade racial e socialmente excludente, viram na guerra de independência uma possibilidade de conquistar algo para melhorar as suas condições de existência. Faltava-lhes educação (formal), mas esse não era o principal ponto de influência para as rebeliões populares de 1814. Depois de 1815, a configuração social da guerra sofreu uma transformação que favoreceu os anticolonialistas e decidiu a independência da Venezuela na batalha de Carabobo em 24 de junho de 1821.

Pelo que se pode inferir, com a queda da Segunda República, depois de ser derrotado pelo exército popular, Bolívar entendeu que era necessário atender a algumas reivindicações das massas populares e foi isso que ele fez depois de 1816. Uma das principais mudanças em sua tática política para atrair os escravos para o exército patriota foi decretar a abolição da escravatura na Venezuela a partir de 1816. Depois da Independência, os Congressistas não aceitaram seus decretos abolicionistas. Em lugar disso, optaram pela abolição do tráfico de escravos e, no que se chamou na Venezuela de Lei de Ventres (ACOSTA SAIGNES, 1997, p. 240), tornaram livres os filhos de escravos que nascessem depois de 21 de julho de 1821, os quais, no entanto, só poderiam deixar o amo de seus pais depois de 18 anos.

\section{Considerações Finais}

A preocupação neste artigo foi discutir alguns fundamentos históricos, com base nos quais Simón Bolívar, a principal liderança política e militar da independência de cinco países 
latino americanos (Venezuela, Colômbia, Equador, Peru e Bolívia), formulou seu ideário de educação para responder tanto às necessidades da implementação e legitimação do Estado moderno na Venezuela quanto aos interesses econômicos dos criollos venezuelanos, no início do século XIX: "Moral e Luzes são nossas primeiras necessidades" (BOLÍVAR, 1982, p. 138).

Vale lembrar que, até o ano de 1816, o projeto político criollo anticolonialista não teve apoio popular, isto é, dos negros - escravos ou não -, mulatos, mestiços, zambos e índios. Logo de início, esses setores entenderam que a proclamação da independência não traria nenhuma mudança prática no que se referia às relações sociais vigentes na época. Como os proclamadores da independência não eram nada mais que os próprios donos de terras e escravos, a Constituição de 1811 mantinha intacta a instituição escravocrata. Os pardos continuaram sendo tratados com indiferença e sua participação nas instituições públicas e políticas tinha as mesmas restrições do período colonial. A expropriação de terras indígenas e o uso servil da força de trabalho indígena continuaram intocáveis. Mesmo na letra da lei, pouco mudara com a proclamação da República.

Simón Bolívar, líder militar e político do processo de independência venezuelana, era um mantuano - branco criollo - e, como tal, compreendia que as mudanças positivas e exclusivas para seu setor social deveriam ser defendidas como mudanças positivas gerais, o que implicava a adesão dos setores populares ao projeto independentista.

Dificilmente os negros escravos iriam sair em defesa da liberdade e igualdade, mantendo-se presos e submetidos a condições extremas de pobreza e de maus tratos. Da mesma forma, aqueles que eram livres, mas sofriam com a discriminação racial, como era o caso dos pardos, também não podiam aderir à causa da liberdade e da igualdade porque, na prática, nada havia mudado. $\mathrm{O}$ mesmo se pode afirmar do índio, que, nas regiões mais povoadas, via cada vez mais reduzida a área de suas reservas pelo avanço das grandes propriedades rurais.

Diante das complexas relações de conflito que a guerra de independência gerou e das rebeliões populares que levaram à queda da Segunda República (1814), mas que tinham sido também decisivas para a queda da Primeira (1812), Bolívar identificava a má educação, a má formação humana daqueles indivíduos, segundo ele, desprovidos dos conhecimentos necessários para saber aproveitar a liberdade, como causa do distanciamento e da oposição dos setores populares aos criollos republicanos.

Como representante de seu setor social, o Libertador lançou sua visão de classe sobre os setores populares, considerando-os ignorantes, amantes da servidão, homens vulgares, 
seres fanáticos, cujas características negativas de sua constituição enquanto seres humanos os fazia rejeitar o paternalismo interessado do mantuanismo.

Em 1819, tendo identificado que a revolta contra os setores dominantes era um problema de educação (formação), Bolívar formulou seu projeto educacional, no qual buscou harmonizar os interesses opostos da luta de classes por meio da educação estatal, pública, gratuita e obrigatória. Ele projetou na educação a possibilidade de controlar os interesses sociais dos setores socialmente marginalizados e criar um consenso em torno dos ideais republicanos do mantuanismo. Seu ideário educativo foi formulado com a finalidade que ele pensava ser imprescindível para a consolidação da República: formar o homem para o amor à pátria, às leis e aos magistrados. Há, portanto, um forte apelo moral em sua proposta formativa.

Depois de 1815, embora a postura do Libertador em relação a esses setores tenha sofrido mudanças consideráveis, como a defesa da abolição da escravatura, sua proposta educacional continuou com a mesma base interpretativa de 1812: não é necessário realizar mudanças sociais e estruturais para que as massas populares defendam o projeto republicano, basta lhes dar uma educação que corrija as deformações "espirituais" que as impedem de assimilar os conceitos de liberdade e igualdade e de respeito à propriedade.

Portanto, o projeto bolivariano de uma educação estatal, pública, gratuita e obrigatória até os doze anos tinha um caráter moralizador e visava corrigir o problema que ele identificava como a causa da insubordinação popular: a ignorância. Essa educação não tinha o sentido de libertação e capacitação individual para a participação na vida política do Estado, porque essa parte da república estava restrita aos setores dominantes, aos senhores ilustrados. A educação, pautada no princípio da formação moral, tinha a função de manter esses homens nos seus setores sociais, passivos diante da política e respeitadores, como sempre lembrava Bolívar (1968, p. 123), “das Leis, da Pátria e dos Magistrados”.

Agradecimentos à CAPES pela bolsa PDSE (Doutorado-sanduíche) no período de abril/2015 a dezembro/2015, na Universidad Pedagógica Experimental Libertador, Caracas, Venezuela.

\section{Referências}

ACOSTA SAIGNES, Miguel. Bolívar acción y utopia del hombre de las dificultades. 2 ed. Caracas: Universidad Central de Venezuela, 1997.

ACOSTA, Vladimir. Algunas cortas reflexiones sobre la participación del pueblo venezolano en la guerra de independencia. Caracas: Colección Difusión, 2014. 
ACOSTA, Wladimir. Independencia, soberanía y justicia social en el pensamiento de Libertador Simón Bolívar.Caracas: Monte Ávila Editores, 2015.

BOLÍVAR, Simón. Discurso de Angostura. In: Escritos del Libertador. Tomo XV. Documentos 3589 - 3592. p. 115, documento 85. Caracas: Sociedad Bolivariana de Venezuela, 1982.

BOLÍVAR, Simón. Discurso de Angostura. In: Escritos del Libertador. Tomo XV. Documentos 3589 - 3592. p. 115, documento 85. Caracas: Sociedad Bolivariana de Venezuela, 1982.

BOLÍVAR, Simón. Discurso pronunciado el 3 de julo de 1811 en la sociedad patriótica de Caracas, por el coronel Simón Bolívar. In: Escritos del Libertador. Tomo IV. Documentos 1 - 287. p. 81, documento 85. Caracas: Sociedad Bolivariana de Venezuela, 1968.

BOLÍVAR, Simón. Memoria dirigida a los ciudadanos de la Nueva Granada por un caraqueño. In: Escritos del Libertador. Tomo IV. Documentos 1 - 287. p. 81, documento 85. Caracas: Sociedad Bolivariana de Venezuela, 1968.

BRITO FIGUEROA, Federico. Historia económica y social de Venezuela. 4 ed. Tomo I. Caracas: Universidad Central de Venezuela, 1974.

BUSHNELL, David. La independencia de la América de Sur española. In: BETHELL, Leslie. Historia de América Latina. Barcelona: Editorial Crítica, 1991.

CARRERA DAMAS, Germán. Boves: aspectos socioeconómicos de la guerra de independencia. Caracas: Monte Avila Editores, 1991.

DÍAZ, José Domingo. Recuerdos sobre la rebelión de Caracas. Caracas: Bilioteca Ayacucho, 2012.

FRANK, Waldo. Nacimiento de un mundo. Caracas: Fundación Editorial el Perro y la Rana, 2006.

LYNCH, John. Los orígenes de la independencia hispanoamericana. In: BETHELL, Leslie. Historia de América Latina. Barcelona: Editorial Crítica, 1991.

MASUR, Gerhard. Simón Bolívar. Caracas: Griialbo, 1987.

PIETRI, Juan Uslar. Historia de la rebelión popular de 1814. Caracas: Monte Ávila Editores, 2014.

VALlENILla LANZ, Laureano. Cesarismo Democrático. Caracas: Eduven, 2000.

Como referenciar este artigo: 
DANCINI, Alex de Novais.; MELO, José Joaquim Pereira. Simón Bolívar: o tratamento das rebeliões populares como um problema educacional. Revista Ibero-Americana de Estudos em Educação, Araraquara, v. 12, n. 2, p. 755-775, 2017. Disponível em: <http://dx.doi.org/10.21723/riaee.v12.n2.8360>. E-ISSN: 1982-5587.

Recebido em: 10/02/2016

Aprovação final em: 04/04/2017 